\title{
Keanekaragaman Makroarthropoda Tanah di Lahan Persawahan Padi Organik dan Anorganik, Desa Bakalrejo Kecamatan Susukan Kabupaten Semarang
}

\author{
Roma Witriyanto, Mochammad Hadi dan Rully Rahadian \\ Laboratorium Ekologi dan Biosistematika, Jurusan Biologi, \\ Fakultas Sains dan Matematika, Universitas Diponegoro \\ Email: roma90prufuture@gmail.com
}

\begin{abstract}
Inorganic paddies system has a negative impact as pests become resistant, environmental pollution and residual hazard. People who are aware of the impact of the application of synthetic chemicals have been applying organic farming. This research aimed to compare the abundance, diversity and dominance of soil macroarthropods in the organic and inorganic paddies field in Village Bakalrejo, Susukan District of Kabupaten Semarang. Sampling of soil macroarthropods method used pit fall traps. Fifteen pit fall traps were set up in the research area and they were divided into three line whith respective line are 5 pit fall traps. Soil macroarthropods which has been found were identified up to family taxon. The results of the research shows abundance of soil macroarthropods organic rice in paddy fields higher (297) than in inorganic paddy fields (236). Diversity of soil macroarthropods in every phase of rice growth (vegetative, reproductive, ripening and post-harvest) was higher in organic paddy fields $(1,479 ; 1,644$; $1,561 ; 1,019)$ than inorganic paddy fields $(1.391 ; 0.595 ; 1.286 ; 1.002)$. Based on the relative abundance index, soil macroarthropods family dominated organic paddy fields in every phase of rice growth (vegetative, reproductive, ripening, and post-harvest) was lower (Gryllidae: 39.4\%; Carabidae: 46.7\%; Formicidae: $44.1 \%$; Formicidae: 48.8\%) than in the inorganic paddy fields (Carabidae: 35.5\%; Carabidae: 57.4\%; Formicidae: 56.3\%; Formicidae: $77.6 \%)$.
\end{abstract}

Key words : biodiversity, soil macroarthropods, organic farming.

\begin{abstract}
Abstrak
Sistem persawahan padi anorganik memiliki dampak negatif seperti hama menjadi kebal, pencemaran lingkungan dan bahaya residu. Masyarakat yang sadar akan dampak aplikasi bahan kimia sintetik kemudian menerapkan pertanian organik. Penelitian ini bertujuan untuk membandingkan kelimpahan, keanekaragaman serta dominansi makroarthropoda tanah di lahan persawahan padi organik dan anorganik di Desa Bakalrejo Kecamatan Susukan Kabupaten Semarang. Metode pengambilan sampel makroarthropoda dilakukan dengan menggunakan pit fall trap. 15 pit fall trap dipasang disetiap lahan dan dibagi menjadi 3 jalur, masing- masing jalur terdapat 5 pit fall trap. Makroarthropoda tanah yang telah didapat kemudian diidentifikasi sampai takson famili. Hasil penelitian menunjukan bahwa data kelimpahan makroarthropoda tanah di lahan persawahan padi organik lebih tinggi (297 ekor) dibanding di lahan anorganik (236 ekor). Keanekaragaman makroarthropoda tanah pada setiap fase pertumbuhan padi (vegetatif, reproduktif, pematangan dan pasca panen) lebih tinggi di lahan organik $(1,479 ; 1,644$; $1,561 ; 1,019)$ daripada lahan anorganik $(1,391 ; 0,595 ; 1,286 ; 1,002)$. Berdasarkan indeks kelimpahan relatif, famili makroarthropoda tanah yang mendominasi lahan organik pada setiap fase pertumbuhan padi (vegetatif, reproduktif, pematangan, dan pasca panen) lebih rendah (Gryllidae: 39,4\%; Carabidae: 46,7\%; Formicidae: 44,1\%; Formicidae: 48,8\%) daripada di lahan anorganik (Carabidae: 35,5\%; Carabidae: 57,4\%; Formicidae: 56,3\%; Formicidae: 77,6\%).
\end{abstract}

Kata kunci : keanekaragaman, makroarthropoda tanah, pertanian organik. 


\section{PENDAHULUAN}

Padi sebagai tanaman pangan penghasil beras merupakan salah satu sumber makanan utama bagi sebagian besar penduduk dunia. Menurut Lampe (1995), beras merupakan bahan makanan pokok untuk lebih dari 2,4 miliar orang di Asia dan ratusan juta orang di Afrika dan Amerika Latin. Menurut Sebayang dkk (2004), kebutuhan akan beras di Indonesia sebagai bahan makanan pokok meningkat sesuai dengan pertambahan penduduk. Namun meningkatnya kebutuhan akan beras tidak dibarengi dengan peningkatan produksi padi, termasuk di Indonesia, sehingga mengharuskan pemerintah untuk mengimpor beras.

Upaya memenuhi kebutuhan beras di dalam negeri masih terkendala sistem pertanian yang kurang tepat. Para petani masih mengaplikasikan pestisida sintetik dan pupuk sintetik yang berlebihan untuk mendapatkan hasil yang lebih maksimal. Namun tanpa disadari semua itu membuat hasil yang didapatkan lama kelamaan justru semakin menurun.

Penggunaan pestisida maupun pupuk sintetik (anorganik) yang berlebihan dan berkepanjangan akan menimbulkan gangguan terhadap keseimbangan ekosistem. Keseimbangan ekosistem yang terganggu karena perlakuan tersebut mengakibatkan terbunuhnya organisme yang ada di sawah baik yang merugikan maupun yang menguntungkan, termasuk arthropoda tanah yang bermanfaat akan banyak berkurang, sehingga berakibat pada melonjaknya populasi hama karena musuh alaminya berkurang dan tidak mampu mengendalikan populasi serangga hama (Untung, 2006).

Arthropoda merupakan filum yang paling besar dalam dunia hewan. Jumlah jenisnya merupakan $80 \%$ dari jumlah jenis hewan yang sudah diketahui. Banyaknya jenis arthropoda dan persebarannya yang luas membuat keberadaanya memiliki dampak yang besar pada ekosistem di bumi.

Makroarthropoda tanah merupakan salah satu kelompok arthropoda. Makroarthropoda tanah di lahan persawahan padi merupakan arthropoda yang hidup dan aktif dipermukaan tanah lahan persawahan padi dan berukuran $2 \mathrm{~mm}-20 \mathrm{~mm}$, memiliki dampak yang besar terhadap ekosistem di sawah. Dengan ukurannya yang lebih besar dari ukuran arthropoda lainnya menjadikan makroarthropoda lebih mudah diamati oleh masyarakat awam sekalipun. Pengamatan tersebut sangat penting untuk melihat apa yang terjadi di dalam ekosistem tersebut. Hal tersebut dikarenakan setiap organisme dalam ekosistem pasti berhubungan dan termasuk dalam jaring - jaring makanan. Makroarthropoda tanah mempunyai peranan penting dalam dekomposisi bahan organik tanah dalam penyediaan unsur hara. Makroarthropoda akan memakan substansi nabati yang mati, kemudian bahan tersebut akan dikeluarkan dalam bentuk kotoran (Arif, 2001).

Di Jawa Tengah Persawahan padi organik sudah mulai banyak dikembangkan. Desa Bakalrejo Kecamatan Susukan Kabupaten Semarang merupakan salah satu desa yang mengembangkan padi organik, kelebihan pertanian organik di desa tersebut sudah diakui dengan adanya sertifikat pangan organik dari Lembaga Sertifikasi Pangan Organik INOFICE.

Penelitian ini bertujuan untuk membandingkan kelimpahan, keanekaragaman, dan dominasi makroarthropoda tanah di lahan persawahan padi organik dan anorganik .

\section{BAHAN DAN METODE}

Penelitian dilakukan di persawahan organik dan anorganik Desa Bakalrejo Kecamatan Susukan Kabupaten Semarang, pada bulan Mei - Oktober 2012. Sedangkan identifikasi dan analisis sampel dilakukan di Laboratorium Ekologi dan Biosistematik, Jurusan Biologi Fakultas Sains dan Matematika, Universitas Diponegoro.

Pengambilan sampel dilakukan di lahan persawahan padi organik dan anorganik (varietas padi IR 64). Sampel diambil dengan menggunakan perangkap sumuran (pit fall trap) yang diisi deterjen untuk mengurangi tegangan permukaan air agar makroarthropoda yang terperangkap bisa tenggelam langsung dan alkohol $70 \%$ agar makroarthropoda yang tertangkap lebih awet atau tidak membusuk (Gressitt \& Gressitt, 1962) .

Gelas plastik yang dipasang sebanyak 15 buah di dalam 3 jalur pematang pada masing - masing lahan. Jarak antara masing - masing gelas plastik adalah 5 meter dalam satu jalur pematang bertujuan sebagai ulangan sampel. Gelas plastik yang telah diisi air detergen ditanam dengan permukaan mulut gelas rata dengan permukaan selama sehari semalam. Penggunaan deterjen bertujuan untuk memperkecil tegangan permukaan air sehingga makroarthropoda yang terperangkap tidak bisa keluar lagi. Pemasangan perangkap sumuran 
dilakukan dua minggu sekali selama satu musim tanam

\section{HASIL DAN PEMBAHASAN}

Hasil penelitian menunjukan bahwa makroarthropoda tanah yang didapat di lahan persawahan padi organik lebih banyak daripada yang didapat di lahan anorganik. Di lahan pertanian organik didapatkan 297 ekor/ 1 musim tanam (kisaran antara 30 sampai 165 individu yang terdapat pada setiap fase pertumbuhan padi) yang terbagi dalam 18 famili, sedangkan di lahan persawahan padi anorganik didapatkan 236 individu/ 1 musim tanam (kisaran 48 sampai 76 individu yang terdapat pada setiap fase pertumbuhan padi) yang terbagi dalam 16 famili. Hal ini sejalan dengan penelitian Suheriyanto (2000) tentang Kajian Komunitas Fauna pada Pertanaman Bawang Merah dengan dan Tanpa Aplikasi Pestisida di Malang didapatkan 43 jenis dengan kelimpahan 1531 ekor di lahan tanpa pestisida sintetik, sementara di lahan yang mengaplikasikan pestisida sintetik didapatkan 40 jenis dengan kelimpahan 1081 ekor.
Famili yang berperan sebagai predator ada 10 famili yaitu Licosidae, Tetragnacidae, Oxyopidae, Coccinelidae, Staphylinidae, Lampyridae, Carabidae, Forficulidae, Pyrrochroridae, Formicidae dan Gryllidae. Sedangkan famili yang termasuk dalam kelompok herbivora ada 8 yaitu : Crysomelidae, Agromyzidae, Pentatomidae, Noctuidae, Grillotalpidae, Acrididae, dan Tettrigidae. Sedangkan kelompok polinator terdapat satu famili yaitu Colletidae.

Perbandingan jumlah makroarthropoda tanah yang terdapat di lahan persawahan padi organik dan anorganik berdasarkan fase pertumbuhan padi dapat dilihat pada Tabel 1. Perbandingan tersebut bersifat saling menggantikan atau tidak ada yang secara kontinyu memiliki jumlah makroarthropoda tanah yang lebih banyak dari semua fase. Hal tersebut terjadi karena letak lahan yang dekat dan berdampingan, sehingga memungkinkan perpindahan makroarthropoda untuk menjaga kelangsungan hidup dengan mencari makan ataupun mencari tempat yang aman.

Tabel 1. Ordo, Famili, dan Jumlah Individu Makroarthropoda Tanah

\begin{tabular}{llllllllll}
\hline Ordo & Famili & \multicolumn{2}{l}{ Vegetatif } & \multicolumn{2}{l}{ Reproduktif } & Pematangan & \multicolumn{2}{c}{ Pasca Panen } \\
\cline { 2 - 9 } & & $\mathrm{O}$ & $\mathrm{AO}$ & $\mathrm{O}$ & $\mathrm{AO}$ & $\mathrm{O}$ & $\mathrm{AO}$ & $\mathrm{O}$ & $\mathrm{AO}$ \\
\hline Araneae & Licosidae (P) & 2 & 1 & 3 & 1 & 1 & 2 & 0 & 1 \\
& Tettragnacidae (P) & 2 & 1 & 1 & 1 & 1 & 0 & 3 & 2 \\
& Oxyopidae (P) & 2 & 0 & 0 & 0 & 2 & 0 & 6 & 0 \\
& Coccinelidae (P) & 0 & 1 & 1 & 2 & 2 & 1 & 0 & 0 \\
& Staphylinidae (P) & 4 & 0 & 0 & 0 & 0 & 0 & 0 & 1 \\
& Lampyridae (P) & 1 & 1 & 1 & 0 & 0 & 0 & 0 & 0 \\
Deleoptera & Carabidae (P) & 43 & 27 & 14 & 31 & 5 & 10 & 0 & 0 \\
Diptera & Crysomelidae (H) & 0 & 0 & 0 & 0 & 0 & 0 & 0 & 1 \\
Hemyptera & Forficulidae (P) & 16 & 1 & 2 & 0 & 11 & 0 & 7 & 0 \\
Hymenoptera & Agromyzidae (H) & 2 & 0 & 1 & 0 & 0 & 0 & 0 & 0 \\
& Pentatomidae (H) & 0 & 1 & 1 & 0 & 3 & 1 & 2 & 1 \\
Lepidoptera & Pyrrhocorida (H) & 0 & 0 & 1 & 0 & 0 & 0 & 0 & 1 \\
Orthoptera & Formicidae (P) & 17 & 13 & 4 & 19 & 26 & 27 & 21 & 45 \\
& Colletidae (PL) & 0 & 0 & 0 & 0 & 1 & 0 & 0 & 0 \\
& Noctuidae (H) & 1 & 0 & 1 & 0 & 2 & 1 & 1 & 2 \\
& Gryllidae (P) & 65 & 22 & 0 & 0 & 5 & 6 & 2 & 0 \\
& Gryllotalpidae (H) & 1 & 6 & 0 & 0 & 0 & 0 & 1 & 2 \\
& Acrididae (H) & 1 & 2 & 0 & 0 & 0 & 0 & 0 & 0 \\
& Tettrigidae (H) & 8 & 0 & 0 & 0 & 0 & 0 & 0 & 2 \\
& JUMLAH & 165 & 76 & 30 & 54 & 59 & 48 & 43 & 58 \\
\hline
\end{tabular}

Keterangan $=$ P: Predator, H: Herbivora, PL: Polinator, O: Organik, AO: Anorganik

Berdasarkan Tabel 1. dapat dilihat juga bahwa fase vegetatif memiliki jumlah makroarthropoda terbanyak dibanding fase yang lain. Hal ini disebabkan karena pada fase ini nutrisi tanah masih tinggi karena sebelum musim tanam dilakukan pengolahan tanah dan pemupukan dulu di lahan organik. Bahan organik dari pupuk tersebut merupakan sumber makanan bagi mikroarthropoda ataupun mesoarthropoda. Sementara itu mikroarthropoda dan mesoarthropoda merupakan salah satu sumber makanan dari makroarthropoda. Selain itu fase vegetatif merupakan fase awal 
pertumbuhan sampai masa pertunasan dimana pada fase tersebut merupakan fase yang disukai oleh makroarthropoda pemakan tumbuhan karena nutrisi yang dibutuhkannya banyak terkandung dalam tanaman pada fase tersebut .

Kelimpahan relatif famili makroarthropoda tanah dapat diketahui dengan perhitungan menggunakan rumus kelimpahan relatif. Berdasarkan Tabel 2. dapat indeks kelimpahan relatif famili yang memperlihatkan tingkat dominansi makroarthropoda di lahan anorganik lebih tinggi daripada makroarthropoda di lahan organik pada setiap fase pertumbuhan padi. Makroarthropoda tanah di lahan persawahan padi organik kelimpahan relatif tertingginya pada setiap fase pertumbuhan padi $(39,4 ; 46,7 ; 44,1 ; 48,8)$ memperlihatkan tingkat dominansinya tidak melebihi 50\%, sedangkan indeks kelimpahan relatif makroarthropoda tanah di lahan anorganik pada setiap fase pertumbuhan padi $(35,5 ; 57,4 ; 56,3 ; 77,6)$ memperlihatkan tingkat dominansi yang rata - rata lebih dari 50\% bahkan pada fase pasca panen tingkat dominansi formicidae mencapai $77,6 \%$. Hal tersebut berkaitan dengan ketersediaan makanan dan faktor bahaya (insektisida). Formicidae terdapat pada semua fase perkembangan padi baik di lahan organik maupun di lahan anorganik dan mempunyai nilai kelimpahan relatif yang tinggi dan selalu naik nilainya dari fase perkembangan vegetatif, reproduktif, pematangan, dan fase pasca panen. Bahkan pada fase pasca panen pada lahan anorganik merupakan nilai kelimpahan relatif tertinggi, sedangkan famili makroarthropoda yang lain nilai kelimpahan relatifnya turun pada fase pasca panen. Hal ini disebabkan karena famili formicidae berperan sebagai predator polifagus yaitu mempunyai banyak jenis makanan, sehingga keberadaannya tidak hanya tergantung dari satu sumber makanan (serangga hebivora) (Jumar, 2000). Menurut Walwork (1976) Hymenoptera (Formicidae ) merupakan salah satu dari 3 ordo yang menduduki $80 \%$ arthropoda tanah selain Acarina dan Collembola.

Tabel 2. Kelimpahan Relatif Famili Makroarthropoda Tanah (\%)

\begin{tabular}{llllllllll}
\hline NO & FAMILI & \multicolumn{2}{l}{ Vegetatif } & \multicolumn{2}{l}{ Reproduktif } & \multicolumn{2}{l}{ Pematangan } & \multicolumn{2}{c}{ Pasca panen } \\
\cline { 3 - 9 } & & O & AO & O & AO & O & AO & O & AO \\
\hline 1 & Licosidae & 1.2 & 1.3 & 10 & 1.9 & 1.7 & 4.2 & 0 & 1.7 \\
2 & Tettragnacidae & 1.2 & 1.3 & 3.3 & 1.9 & 1.7 & 0 & 7 & 3.4 \\
3 & Oxyopidae & 1.2 & 0 & 0 & 0 & 3.4 & 0 & 14 & 0 \\
4 & Cocinelidae & 0 & 1.3 & 3.3 & 3.7 & 3.4 & 2.1 & 0 & 0 \\
5 & Staphylinidae & 2.4 & 0 & 0 & 0 & 0 & 0 & 0 & 1.7 \\
6 & Lampyridae & 0.6 & 1.3 & 3.3 & 0 & 0 & 0 & 0 & 0 \\
7 & Carabidae & 26 & $\mathbf{3 5 . 5}$ & $\mathbf{4 6 . 7}$ & $\mathbf{5 7 . 4}$ & 9.3 & 20.8 & 0 & 0 \\
8 & Crysomelidae & 0 & 0 & 0 & 0 & 0 & 0 & 0 & 1.7 \\
9 & Forficulidae & 9,7 & 1.3 & 6.7 & 0 & 20.4 & 0 & 16.3 & 0 \\
10 & Agromyzidae & 1.2 & 0 & 3.3 & 0 & 0 & 0 & 0 & 0 \\
11 & Pentatomidae & 0 & 1.3 & & 0 & 5.1 & 2.1 & 4.7 & 1.7 \\
& & & & 3.3 & & & & & \\
12 & Pyrrhocoridae & 0 & 0 & 3.3 & 0 & 0 & 0 & 0 & 1.7 \\
13 & Formicidae & 10.3 & 17.1 & 13.3 & 35.2 & $\mathbf{4 4 . 1}$ & $\mathbf{5 6 . 3}$ & $\mathbf{4 8 . 8}$ & $\mathbf{7 7 . 6}$ \\
14 & Colletidae & 0 & 0 & 0 & 0 & 1.7 & 0 & 0 & 0 \\
15 & Noctuidae & 0.6 & 0 & 3.3 & 0 & 3.4 & 2.1 & 2.3 & 3.4 \\
16 & Gryllidae & $\mathbf{3 9 . 4}$ & 28.9 & 0 & 0 & 8.5 & 12.5 & 4.7 & 0 \\
17 & Gryllotalpidae & 0.6 & 7.9 & 0 & 0 & 0 & 0 & 2.3 & 3.4 \\
18 & Acrididae & 6 & 2.6 & 0 & 0 & 0 & 0 & 0 & 0 \\
19 & Tettrigidae & 4.8 & 0 & 0 & 0 & 0 & 0 & 0 & 3.4 \\
\hline
\end{tabular}

Keterangan: $\mathrm{O}=$ organik, $\mathrm{AO}=$ anorganik, cetak tebal = kelimpahan relatif tertinggi 
Indeks keanekaragaman $\quad\left(\mathrm{H}^{\prime}\right)$ makroarthropoda tanah dihitung menggunakan rumus indeks keanekaragaman Shannon-Wiener. Berdasarkan Tabel 3., Nilai indeks keanekaragaman makroarthropoda tanah pada lahan organik lebih tinggi daripada yang ada di lahan anorganik. Hal itu disebabkan karena pengelolaan lahan pertanian pada lahan anorganik menggunakan insektisida sintetik yang mengakibatkan kematian atau perpindahan makroarthropoda yang hidup di lahan tersebut, sehingga nilai indeks keanekaragamannya menurun. Odum (1993) menyatakan bahwa nilai keragaman akan cenderung lebih rendah pada ekosistem yang mengaplikasikan pestisida sintetik dan nilai keragaman akan tinggi pada ekosistem yang diatur secara biologi. Indeks keanekaragaman makroarthropoda pada lahan persawahan padi organik dan anorganik sesuai fase perkembangan padi tergolong sedang, kecuali pada fase reproduktif pada lahan anorganik yang bernilai rendah. Rendahnya indeks keanekaragaman makroarthropoda tanah pada lahan anorganik pada fase reproduktif menggambarkan disana hanya terdapat 5 famili dan jumlahnya didominasi oleh dua famili (Carabidae dan Formicidae) dengan jumlah individu 31 dan 19 individu, sementara jumlah total individu dari kelima famili tersebut hanya 54 individu. Keberadaan jumlah yang menonjol dari formicidae dan carabidae disebabkan oleh karakter makroartropoda tersebut yang hidup di lorong - lorong tanah ataupun di bawah batu serta benda lain sehingga memungkinkan mereka untuk terhindar dari insektisida sintetik dan kemungkinan mereka lebih tahan terhadap insektisida sintetik daripada yang lain.

Berdasarkan Tabel 3., diketahui indeks kemerataan makroarthropoda tanah pada lahan organik berdasarkan fase pertumbuhan padi berkisar antara 0,49 - 0,686 artinya tingkat kemerataan famili makroarthropoda berkisar $49 \%$ - 69\% pada fase pertumbuhan padi di lahan organik. Sedangkan pada lahan anorganik indeks kemerataannya berkisar antara $0,435-0,661$ artinya tingkat persebaran famili makroarthropoda pada lahan anorganik antara 44\% - 66\%. Dari data tersebut secara umum kemerataan famili makroarthropoda tanah di lahan organik lebih tinggi sedikit daripada kemerataan famili di lahan anorganik, tetapi keduanya sama - sama termasuk dalam kriteria kemerataan yang sedang sampai tinggi.

Tabel 3. Keanekaragaman (H'), Kemerataan (E) Makroarthropoda Tanah

\begin{tabular}{lllllllll}
\hline & \multicolumn{2}{l}{ Vegetatif } & \multicolumn{2}{c}{ Reproduktif } & \multicolumn{2}{c}{ pematangan } & \multicolumn{2}{c}{ pasca panen } \\
\cline { 2 - 9 } & $\mathrm{O}$ & $\mathrm{AO}$ & $\mathrm{O}$ & $\mathrm{AO}$ & $\mathrm{O}$ & $\mathrm{AO}$ & $\mathrm{O}$ & $\mathrm{AO}$ \\
\hline Jumlah Individu & 165 & 76 & 30 & 54 & 59 & 48 & 43 & 58 \\
Jumlah Famili & 14 & 11 & 11 & 5 & 11 & 7 & 8 & 10 \\
$\begin{array}{l}\text { Indeks } \\
\text { Keanekaragaman }\end{array}$ & 1,749 & 1,391 & 1,644 & 0,959 & 1,561 & 1,286 & 1,019 & 1,002 \\
$\begin{array}{l}\text { Indeks } \\
\text { Kemerataan }\end{array}$ & 0,663 & 0,58 & 0,686 & 0,596 & 0,651 & 0,661 & 0,49 & 0,435 \\
\hline
\end{tabular}

Keterangan: O: Organik, AO: Anorganik

Dari Tabel 3. dapat dilihat ada fenomena yang menarik pada fase pematangan dimana indeks kemerataan famili makroarthropoda tanah di lahan pertanian organik lebih rendah dari indeks kemerataan famili makroarthropoda tanah di lahan anorganik. Hal itu disebabkan pada fase tersebut kemungkinan dilakukan pemberian insektisida organik, sehingga makroarthropoda yang ada pada lahan organik berpindah tempat (sifat insektisida yang hanya mengusir). 
Tabel .4. Indeks Kesamaan (Sorensen) di Pertanian Padi Organik dan Anorganik

\begin{tabular}{lcccc}
\hline Vegetatif & Vegetatif & Reproduktif & Pematangan & $\begin{array}{c}\text { Pasca } \\
\text { panen }\end{array}$ \\
Reproduktif & 0,72 & - & - & - \\
Pematangan & - & 0,63 & - & - \\
Pasca panen & - & - & 0,78 & - \\
\hline
\end{tabular}

Keterangan: $\mathrm{O}=$ Organik, $\mathrm{AO}=$ Anorganik

Indeks kesamaan famili menggambarkan tingkat kesamaan famili yang ada pada dua habitat dengan uji Sorenson (Odum ,1993). Berdasarkan tabel 4. makroarthropoda tanah yang ada pada lahan persawahan padi organik dan lahan persawahan padi anorganik Desa Bakalrejo Kecamatan Susukan Kabupaten Semarang memiliki tingkat kesamaan famili lebih dari $50 \%$ (berkisar antara 56\% sampai 78\%). Menurut Suin (1991) dua ekosistem dikatakan memiliki persamaan komunitas bila indeks kesamaannya lebih dari $50 \%$. Perbedaan yang terjadi karena adanya faktor lain yang mempengaruhi komunitas tersebut. Kesamaan famili makroarthropoda tanah disebabkan oleh letak lahan yang dekat dan saling bersebelahan sehingga memungkinkan makroarthropoda yang aktif bergerak untuk berpindah dari lahan organik ke lahan anorganik atau sebaliknya.

Indeks kesamaan famili yang naik turun menunjukan adanya kematian ataupun perpindahan makroarthropoda tanah untuk mencari makan ataupun menghindari sesuatu yang berbahaya (pestisida) ke lahan yang lebih aman bagi mereka, dan hal tersebut terkait dengan fase pertumbuhan padi.

\section{KESIMPULAN}

- Kelimpahan makroarthropoda tanah di lahan persawahan padi organik dengan 297 ekor/ satu musim tanam lebih tinggi dibanding kelimpahan di lahan anorganik dengan 236 ekor/ satu musim tanam.

- Keanekaragaman makroarthropoda tanah di lahan persawahan padi organik pada semua fase pertumbuhan padi lebih tinggi dibandingkan keanekaragaman makroarthropoda di lahan persawahan padi anorganik.

- Makroarthropoda tanah yang paling dominan pada lahan padi organik fase vegetatif adalah Gryllidae, sedangkan di lahan anorganik adalah Carabidae, untuk fase reproduktif kedua lahan didominasi oleh Carabidae, sedangkan fase pematangan dan pasca panen kedua lahan didominasi oleh Formicidae.

\section{DAFTAR PUSTAKA}

Arief, A. 2001. Hutan dan Kehutanan. Jakarta: Kanisius. hal. 179.

Gressitt, J. L. \& M. K. Gressitt. 1962. An Improved Malaise Trap. Pacific Insects 4: 87-90.

Jumar. 2000. Entomologi Pertanian. Penerbit Rieneka Cipta. Jakarta.

Lampe, K. 1995. Rice Research : Food for 4 Billion People. Geo-Journal 35 (3) : 258259.

Odum, E. 1993. Dasar-Dasar Ekologi. Penerjemah: Tjahyono Saminginan. Gadjah Mada University Press. Yogyakarta.

Sebayang, Sudiarso, \& Lupirinita.. 2004. Pengaruh Sistem Tanam dan KombinasiPemupukan Organik dan Anorganik Pada Pertumbuhan dan HasilTanaman Padi Sawah (Oryza sativa L). Habitat 15(2).

Suheriyanto. 2000. Kajian Komunitas Fauna Tanah pada Pertanaman Bawang

Merah dengan dan Tanpa Aplikasi Pestisida. Universitas Brawijaya. Malang.

Suin, N.M. 1991. Perbandingan Komunitas Hewan Permukaan Tanah Antara Ladang dan Hutan di Bukit Pinang-Pinang Padang. Laporan Penelitian Universitas Andalas, Padang.

Untung, K. 2006. Pengantar Pengelolaan Hama Terpadu. Gadjah Mada University Press. Yogyakarta.

Wallwork, J.A. 1976. The Distribution and Diversity of Soil Animal. Mc GrawHill. London 
BIOMA, Juni 2015

Vol. 17, No. 1, Hal. 21-26

ISSN: 1410-8801 